\title{
The origin of cystitis and it's elimination ,the use of natural effect in treatment
}

\author{
Lutfullo VAHOBOV ${ }^{1}$ \\ Andijan State Medical Institute
}

\begin{tabular}{l} 
ARTICLE INFO \\
\hline Article history: \\
Received April 2021 \\
Received in revised form \\
20 April 2021 \\
Accepted 15 May 2021 \\
Available online \\
25 June 2021 \\
\hline
\end{tabular}

Keywords:

phytotherapy,

cystitis,

treatment.
ABSTRACT

This article provides information on cystitis, one of the most common diseases today, new methods of treatment and tips to eliminate its origin. Information is provided on what cystitis is, how it occurs, its symptoms, complications, and natural methods used in treatment.

2181-1415/CC 2021 in Science LLC.

This is an open access article under the Attribution 4.0 International (CC BY 4.0) license (https://creativecommons.org/licenses/by/4.0/deed.ru)

\section{Sistit kasalligini kelib chiqishi va uni bartaraf etish, davolashda tabiiy samarali usullardan foydalanish}

\section{Kalit so'zlar:}

fizioterapiya,

sistit,

davolash.
ANNOTATSIYA

Ushbu maqolada, bugungi kunda ko'p uchrayotgan kasalliklardan biri bo'lgan sistit kasalligi haqida, uni davolashni yangicha usullari va kelib chiqishini bartaraf etish uchun maslahatlar berilgan. Sistit kasalligi o'zi nima, qanday kelib chiqadi, simptomlari, asoratlari haqida va davolashda foydalaniladigan tabiiy usullar haqida ma'lumotlar berilgan.

\footnotetext{
${ }^{1}$ Assistant, Andijan State Medical Institute, Andijan, Uzbekistan.
} 


\section{Возникновение цистита и его устранение, использование природных эффективных методов в лечении}

\author{
Ключевые слова \\ физиотерапия, \\ цистит, \\ лечение.
}

\begin{abstract}
АННОТАЦИЯ
В данной статье представлена информация о цистите, одном из самых распространенных на сегодняшний день заболеваний, новых методах лечения и советы по устранению его происхождения. Предоставляется информация о том, что такое цистит, как он возникает, его симптомах, осложнениях и естественных методах лечения.
\end{abstract}

Cystitis is an infectious disease, the causative agent of which is $85-95 \%$ of E. coli. The infection can enter the bladder through the skin, or through an ascending pathway from the rectum.

\section{Where cystitis occurs.}

1. As mentioned, in women, the shortness of the urethra and the size of the bladder allow the spread of infection.

2. Another cause is microtraumas of the female urethra. There is a term "honey cystitis".

3. The development of cystitis in men is often due to prostate disease, kidney stones or diabetes mellitus, it is observed at the expense of men who have forgotten the rules of hygiene, is observed at the expense of labyrinthine. observed that they develop under the influence of chlamydial mycoplasma or trichomonads.

4. In all cases, a general urine and blood test, microflora culture, ultrasound examination of the bladder, or cystoscopy are performed.

\section{What to do in cystitis?}

1. It is advisable to stay in bed, to stay warm, to put a hot water heater in the bladder area (it is not necessary to put a water heater if there is no blood mixture with urine).

2. It is recommended to drink plenty of fluids (tea with milk). Coffee and beer are denied. When blood is added to the urine - it is recommended to drink tinctures of scorpion grass (nettle).

3. For phytotherapy purposes, pharmacies have a complex of ready-made herbs, as well as uroseptics prescribe cystone, canephron, phytolysin. Diet is prohibited to eat pryanostey, canned food, marinated products at various firing. Dairy products, fruits, melons (watermelon) are the same.

4. Avoid going to the bath and sauna, it is better to get used to bathing in accordance with the rules of hygiene.

5. No-spa drink, the use of papaverine candles is effective not only against pain syndrome but also against inflammation.

6. Antibacterial drugs in all cases Monurol - 3 mg once a day 2 hours after a meal, Nolitsin, 1 tablet 2 times a day for 3 days or biseptol 2 tablets 2 times a day.

7. Among the biologically active substances UROPROFIT® contains antispasmodic, anti-inflammatory and antimicrobial components.

8. In recurrent cystitis, diabetes mellitus, the course of treatment lasts longer. Biseptol and Nolitsin, Furadonin and Tetracycline are not available for pregnant women. For them, amoxicillin or cefuroxime is the same. 10. If dysuric complaints are accompanied by pain and fever in the lumbar region, the inflammation is considered to have passed to the kidneys, and in these cases it is definitely recommended to see a doctor 


\section{Causes of cystitis}

There is a belief that a woman can "catch" the disease on a cold day by sitting lightly on some concrete parapet or swimming in a pool of cold water. In fact, cystitis has nothing to do with colds.

The "provocateurs" of cystitis are various microorganisms that cause inflammation of the urinary tract and bladder. Often, common E. coli acts as the causative agent of the infection. These bacteriaoften enter the urethra during sex (i.e., pay for bed experiments).

Note: With the advent of daily sanitary napkins, women have become more prone to cystitis. This is due to the accumulation of various bacteria along with secretions from intimate areas on the surface of hygiene products.

Given that the urethra in women is relatively short and wide, it is not difficult for microorganisms to enter it and reach the bladder. Hypothermia not only contributes to the development of the disease, the decline of immunity. Other causes of cystitis include disordered hygiene of the genitals, use of various intimate gels.

\section{What happens if cystitis is not treated?}

Don't expect anything good from it. Cystitis, which is initially untreated or slightly affected by medication, progresses to the latent stage of the course. Then it gradually takes root as chronic.

Well, already starting from this position, it opens "like a business", "eating" from the inside of the bladder and reaching the kidneys.

Therefore, half-measures in the treatment of cystitis will not be enough to get rid of the unpleasant disease. Ideally, you should consult your doctor to prescribe antibacterial medications.In parallel, you can resort to folk methods of treating cystitis - recovery comes faster and is as complete as possible. In addition, home remedies for cystitis provide excellent prevention of recurrence of the disease.

\section{Folk medicine for the treatment of cystitis}

It is best to stay in bed for the first three days of cystitis treatment. If the body temperature is within the physiological norm, then warm sitz baths with herbs can and should be included in the list of antisytic agents. If there is no blood in the urine during urination, you can use a warm heater. Even two! One is in the lower abdomen and the other is in the perineum.

\section{Chamomile baths for cystitis}

A proven method of treating cystitis is a chamomile bath. Prepare a classic chamomile tincture, pull it directly into the bath. You will need about a liter of infusion. Bath water should be moderately warm. Needle baths for cystitis Boil half a kilo of pine needles in boiling water, insist and prepare a hot bath with broth. You can drop the broth and sit on the steamed pine needles wrapped directly around the bottom in the bath. In a properly prepared infusion, the needles are soft and do not stumble.

\section{Herbal baths for cystitis}

Contains a set of medicinal herbs - chamomile, St. John's wort, yarrow - to infuse, gently moisten to get a strong infusion and use to prepare a medicinal bath. After the bath, put on flannel underwear and use the heating pad.

\section{Dry bath for cystitis}

The old rustic method: heat half of the red clay brick, throw it in a dry enamel bucket and sprinkle the dried chamomile on top. Make a hole in the middle of the bucket with a wooden circle wrapped in cloth, take off your laundry and sit down. Wrap a blanket around 
the top. Take such a dry bath until you feel a noticeable heat from the brick. Then immediately put on flannel underwear (for example, it can be heated on the radiator), go to bed and put a heating pad on your bed.

Steam bath for cystitis.

Pour boiling water over a whole grain of oats (a handful), boil for five to ten minutes, pour a glass of dry horseradish into the broth. Close the lid and leave on low heat for three minutes. Then pour the broth into a suitable container (ideally, a classic night vase), don't sit around to avoid burning yourself.

If the broth is hot, take a steam bath. Usually 10-15 minutes.

Immediately after the procedure, put on flannel underwear, avoid cooling, and lie down on a heated bed with heated beds. Put a heating pad on the perineum. Antiinflammatory and diuretic teas for cystitis. Treatment with baths should be combined with the reception of anti-inflammatory and diuretic drinks. You can make them based on pharmacy fees or the medicinal herbs you find at home.

\section{Lingonberry tea}

Cook dried or fresh lingonberry with a liter of boiling water with lingonberry leaf (half a cup of this and that). Cover the teapot with a warm cloth and wait for twenty minutes. Drink the drink like regular tea, add honey and lemon if desired.

\section{REFERENCES:}

1. Aylamazyan E.K. Violation of the гергоducthe system / E.K. Aylamazyan // Gyтесology. - 2008. - PP. 65-74.

2. The role of ultraseund in integтateddymamie monitoring of patients with delayed puberty / A.A. Bogdanov Jet al.] // Obstetrics and Gynecology. - 1991. - 8. P. 55-59.

3. Bulanov M.N. Uirasounddingrosties in gynecological pгасtice / M.N. Bulanav. - M. The medicine, 2002. - PP. 154-165.

4. Begdanore E.A. Cinie, diagnosis and treatment of PA in girtis / E.A. Bogdarova // Obstetrician.ginekol. 1984. - N 8. - PP. 61-65.

5. Evtushenko I.D. Comparative ultrasound pieture of the pelvieorgans in patients with secordary amenor-rhea and in women with a regular menstrual cycle/ L.D. Evtushenka, I.G. Rutsenka, O.V. Artemova // Ultra- sound. and diagnostics. - 2004. N 1. - P. 124. 